> and principal investigator on the mission.

In 1995, a probe dropped by the Galileo mission found many volatile elements, such as nitrogen and argon, in higher proportions than expected at Jupiter's distance from the Sun. This suggested that Jupiter either migrated to its current location after forming elsewhere, or that it incorporated many comet-like building blocks from the Solar System's colder reaches. But because the probe descended through a rare dry spot with little water vapour, Galileo could not get a global read for Jupiter's oxygen. That left "a big hole" in what researchers know about the planet, says Tobias Owen at the University of Hawaii in Hilo, an investigator on the Galileo and Juno missions. This time, Juno will try to measure water content by detecting microwaves emitted by Jupiter's atmosphere. The amount of water present at different depths in the atmosphere alters the strength of the emission at different frequencies.

If Jupiter proves to be as enriched in oxygen as it is in other volatiles, that could lend support to a colder, more distant origin. Alternatively, the presence of even more oxygen would bolster models proposing that Jupiter formed close to its present orbit, with water ice trapping other volatiles. And if the global oxygen abundance is as low as that found by Galileo, "then we really have to open ourselves up to new ideas," says Bolton.

Another key Juno experiment will try to identify whether Jupiter has a core - the roughly ten Earth masses of ice and rock that many theorists say would have been necessary to allow the runaway accretion of the hydrogen and helium gases that make up most of the planet. The experiment will look for the subtle effect that a core's gravitational $\begin{array}{ll}\text { "Understanding } & \text { pull would have } \\ \text { the history of } & \text { spacecraft. }\end{array}$ the history of water across the early Solar System is a fundamental question."

But Alan Boss, a theorist at the Carnegie Institution for Science in Washington DC, says that the presence or absence of a core won't determine Jupiter's origin conclusively. There is an alternative formation model, called disk instability, in which a perturbation in a thick cloud of gas can cause it to shrink rapidly to form a giant planet and this model works with or without a core. Moreover, Boss says, Jupiter's core could have changed over time. And, he says, laboratories on Earth are just beginning to understand the behaviour of the highly compressed hydrogen that makes up the bulk of Jupiter's interior, and which matters most in understanding its structure. "To claim that Juno will solve the question of Jupiter's formation doesn't seem to be supported by what we know right now," he says. But Bolton says that the data will certainly help to constrain the theorists. "Slowly, you can put the handcuffs on these guys," he says.

All the debate assumes that Juno will survive long enough to get the data. Engineers have tried to protect it from the intense radiation, placing instruments behind elaborate periscope-like mirrors, and putting the most vulnerable electronics into a titanium box known as 'the vault'. Even so, Juno's design limits it to just 33 polar orbits, one every 11 days, before it is sent plunging into Jupiter, to avoid the risk of its hitting the moon Europa and possibly contaminating it with terrestrial microbes.

Within those precious orbits, Bolton hopes that his team can
ONATURE.COM Take a video tour of Juno's mission: go.nature.com/sosnyi

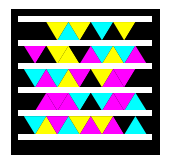

Scan the tag above with the free app from gettag.mobi begin to understand how Jupiter was made - a question that has grown more relevant with the discovery of many Jupiter-mass planets in distant solar systems. "Jupiter is our archetype," Bolton says. "It's the only one we have." -

\title{
Court quashes stem-cell lawsuit
}

\section{USjudge throws out case meant to halt federal funding, but research remains vulnerable.}

\section{BY MEREDITH WADMAN}

$\mathrm{W}$ as the case a fluke or a forewarning? Now that a federal judge has thrown out a lawsuit that sought to halt US government funding of research using human embryonic stem cells, scientists who depend on that support are left wondering whether the battle is truly over, or is merely moving on to a different arena.

Chief Judge Royce Lamberth of the US District Court for the District of Columbia issued his decision on 27 July, acknowledging a higher court's opinion that overruled a preliminary injunction that he had placed to suspend the funding last August (see 'Trying times'). That injunction was in effect for only 17 days, but it threw the stem-cell research community into turmoil as hundreds of scientists faced a funding cut-off. All research on human embryonic stem cells at the US National Institutes of Health (NIH) in Bethesda, Maryland, was shut down and reviews of grant applications were left in limbo.

Last week's ruling decisively affirms the government's legal ability to fund research on human embryonic stem cells. It is a significant blow to the plaintiffs in the case - James Sherley, a biological engineer at the Boston Biomedical Research Institute in Massachusetts, and Theresa Deisher, who runs AVM Biotechnology in Seattle, Washington. Both work with adult stem cells, which are isolated from tissues or organs rather than embryos. Speaking

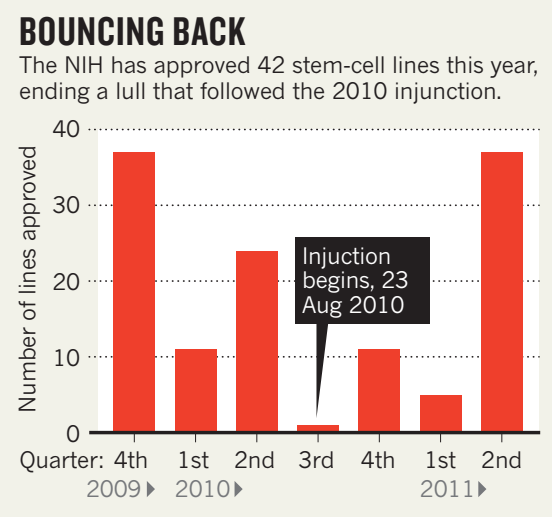

to Nature on the day of Lamberth's decision, Deisher said: "It seems to be a complete reversal from his ruling last summer, so obviously it's quite a surprise."

"We intend to review all of our options for appeal of this decision," says Steven Aden, a lawyer for the plaintiffs.

Legal experts say that any appeal by the plaintiffs will probably not be successful, given the strength of Lamberth's written opinion and the fact that the appeals court overturned the preliminary injunction. "They are likely to lose at every stage," says Alta Charo, who studies law and bioethics at the University of Wisconsin-Madison. She adds that the injunction may come to be seen as an anomaly, rather than as encouragement for those who aim to starve human embryonic stem-cell research of funding. "I think it's a one off," she says.

But for scientists who laboured under the threat of a funding shutdown for 11 months as the case unfolded, the outcome is bittersweet. Although NIH approval of new stemcell lines has resumed, and even accelerated (see 'Bouncing back'), some say that it will 
take years to recover from the impact of the shutdown. Scientists who left the field in the interim might never return.

“Things have changed permanently. It's not just going to go back to the way it was - not immediately," says Meri Firpo, who researches stem-cell therapies at the University of Minnesota Stem Cell Institute in Minneapolis.

Candace Kerr, a stem-cell scientist at the Institute for Cell Engineering at Johns Hopkins University in Baltimore, Maryland, had $\mathrm{NIH}$ funding for human embryonic stem-cell work at the time of the shutdown, but has since moved entirely to work with induced pluripotent stem cells - adult cells that have been reprogrammed to act as stem cells. She has no plans for future studies on human embryonic stem cells. "The shock of what happened last year, coming out of nowhere, makes us really sceptical about moving forward," says Kerr.

Such scepticism may be warranted, given the history of political division over the scientific use of donated embryos in the United States. When issuing his injunction last year, Lamberth ruled that the NIH had violated a 1995 law, the Dickey-Wicker amendment, which forbids the government to fund "research in which a human embryo or embryos are destroyed". Three presidential administrations have interpreted the amendment to permit funding for research on lines of human embryonic stem cells, but not for the creation of such lines, which requires destruction of embryos. In 2001, US President George W. Bush restricted the funding to research involving a small number of existing lines. His successor, President Barack Obama, lifted this restriction in 2009, prompting the approval of dozens of new stem-cell lines; groups that oppose the research on moral grounds then launched a lawsuit to halt the funding. Sherley and Deisher were granted standing in the case after arguing that funding for human embryonic stem cells harmed their prospects of receiving NIH grants for their own research on adult stem cells.

The government appealed Lamberth's preliminary injunction, leading the appeals court first to place a temporary hold on the injunction and then, in April, to strike it down altogether, sending the case back to Lamberth's
To read more about the stem-cell lawsuit, visit: go.nature.com/ljonzx court. Last week, constrained by the appealscourt decision, Lamberth rejected Sherley and Deisher's lawsuit. His written opinion attacked all of the plaintiffs' key arguments, finding that the Dickey-Wicker amendment's wording is "ambiguous" and that the NIH's interpretation that it allows funding of human embryonic stem-cell research is "reasonable", thus satisfying an administrative-law doctrine that courts must to defer to an agency's reasonable interpretation of an ambiguous law.

Hank Greely, director of the Center for Law and the Biosciences at Stanford University in California, says it is very likely that the appeals court will hold to the same position if the plaintiffs try to appeal the latest decision. "Then the only remaining hope for the plaintiffs is the Supreme Court," he says. The US Supreme Court accepts only about $1 \%$ of the thousands of cases it is asked to hear each year.

Nonetheless, human embryonic stem-cell research remains vulnerable. Charo notes that the current US Congress is so politically divided it is unlikely to enact a law either explicitly permitting or explicitly prohibiting government funding for the research. But, she says, "nothing in this decision and nothing in the Dickey-Wicker amendment" stops a new president from quashing research simply by refusing to fund it. Greely says that the best way to protect the research "is to get some real medical progress with stem cells" to prove the worth of the field.

Kerr agrees. "The only way this debate's going to end is with a cure," she says.

The irony is that this will only happen if enough researchers commit to developing the field's potential - and they may be put off by the lawsuit's lingering shadow. "There has been one source of uncertainty after another," says Sean Morrison, outgoing director of the Center for Stem Cell Biology at the University of Michigan in Ann Arbor. In 2008, Morrison campaigned successfully to protect research involving human embryonic stem cells in the state's constitution, but in the past six months he has returned to earlier work with adult stem cells, which he will continue when he takes up a position at the University of Texas Southwestern Medical Center in Dallas this month.

"Eventually," says Morrison, "everyone starts looking around and saying, 'There's got to be easier ways to do science."” - SEE EDITORIAL P.5

\section{TRYING TIMES}

After an injunction against it, US courts upheld funding for stem-cell science.

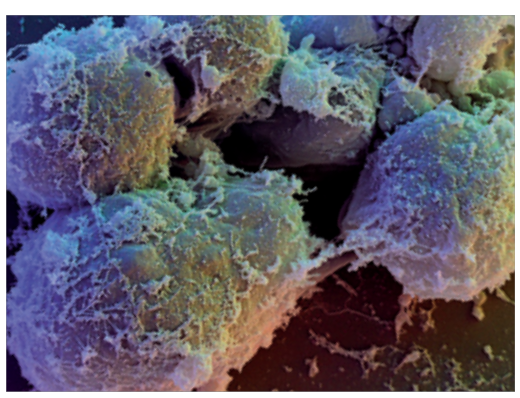

\section{AUGUST 2010}

Chief Judge Royce Lamberth of the US District Court for the District of Columbia issues an injunction suspending federal funding of research on human embryonic stem cells (pictured above).

\section{SEPTEMBER 2010}

The US Court of Appeals for the District of Columbia Circuit temporarily stays the Lamberth injunction.

\section{DECEMBER 2010}

The appeals court hears oral arguments for and against the preliminary injunction.

\section{APRIL 2010}

The appeals court permanently overturns the preliminary injunction.

\section{JULY 2011}

Lamberth (pictured, below), ruling on the merits, throws out the lawsuit. Plaintiffs' attorneys say they will "review all of our options for appeal".

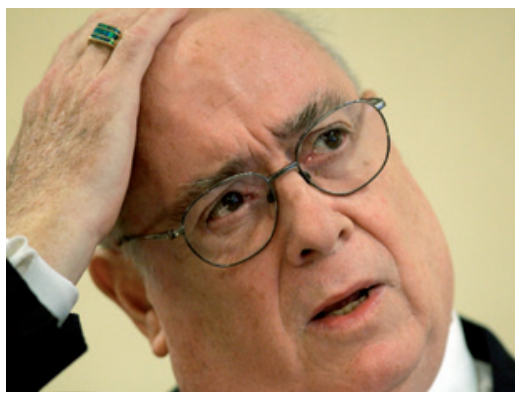

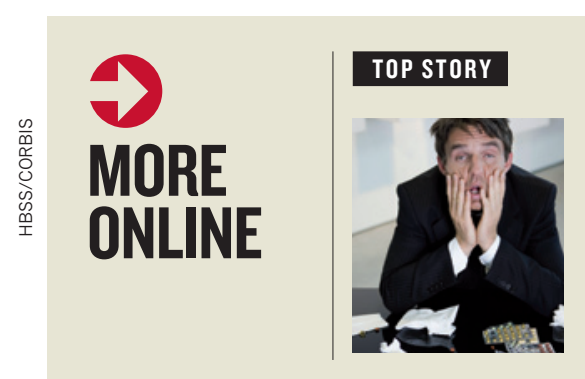

Antibody that binds all influenza A strains could be blueprint for universal vaccine go.nature.com/naecyt

\section{OTHER NEWS}

- How to design safer chemicals go.nature.com/19hzcy

- Russian submersible Mir takes a dive into Lake Geneva go.nature.com/ kqlezr

- Survey of depression in China holds some surprises go.nature.com/7q4iuk

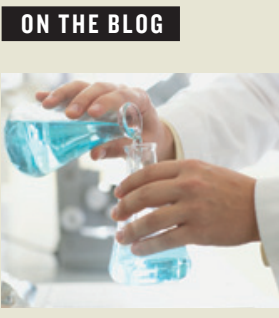

Science tries to look useful as US budget cuts loom go.nature.com/ asr5ho 